suggest that the other components of gall bladder bile, such as phospholipids, do not exert a protective action as they seem to do when the effect of bile acids on the mucosa of the small intestine is studied (Russell et al., 1973 a, b; Wingate et al., 1973). The effects of individual bile acids thus need to be specifically defined. Ivey et al. (1970) showed that TCA alone caused qualitative and quantitative ionic changes in the stomach similar to those induced by a bile acid mixture.

The results of this study confirm the effects of aspirin on the gastric mucosal barrier, as measured by a change in gastric mucosal E.P.D. (Geall et al., 1970; Murray et al., 1974). The results of this study show that the effect of TCA on gastric mucosal E.P.D. is similar to that of aspirin. A combination of aspirin and TCA caused a similar significant alteration in gastric mucosal E.P.D. in our study, but the duration of change was significantly longer than that obtained with aspirin or TCA alone. Semple and Russell (1975) showed that exposure of rats to a combination of TCA and aspirin leads to an increased incidence of gastric haemorrhagic mucosal bleeding as compared to the incidence in rats exposed to aspirin or TCA alone. Our results confirm that the gastric mucosal barrier is significantly broken for a significantly longer time when the combination of aspirin and TCA is used in man. As a longer duration of gastric mucosal barrier breaking will allow a more prolonged back diffusion of $\mathrm{H}^{+}$ions and, subsequently, a longer increase in capillary permeability it may well be that significant gastric mucosal haemorrhage is more likely to occur under such circumstances.

The results of this study thus indicate that the ingestion of aspirin, together with the coincident reflux of bile from the duodenum, may be a factor in the pathogenesis of significant aspirin-induced gastric mucosal damage in some patients.

\section{References}

Bedi, B. S., et al. (1971). Gastroenterology, 60, 256

Black, R. B., Hole, D., and Rhodes, J. (1971). Gastroenterology, 61, 178.

Black, R. B., Rhodes, J., and Hole, D. (1973). Digestive Diseases, 18, 411.

Brodie, D. A., and Chase, B. J. (1967). Gastroenterology, 53, 604.

Cochran, K. M., and Russell, R. I. (1973). Gut, 14, 903.

Croft, D. N., and Wood, P. H. N. (1967). British Medical fournal, 1, 137.

Davenport, H. W. (1967). New England fournal of Medicine, 276, 1307.

Davenport, H. W. (1968). Gastroenterology, 54, 175.

Davenport, H. W. (1969). Gastroenterology, 56, 439.

Dowling, H. R., and Small, D. M. (1968). Gastroenterology, 54, 1291.

Du Plessis, D. J. (1965). Lancet, 1, 974.

Geall, M. G., Phillips, S. F., and Summerskill, W. H. J. (1970 a). Gastroenterology, 58, 437.

Geall, M. G., et al. (1970 b). Gut, 11, 34.

Grant, R., et al. (1951). Fournal of Cellular and Comparative Physiology, 37, 137. Ivey, K. J., Denbesten, L., and Clifton, J. A. (1970). Gastroenterology, 59,

Ivey, K. J., Denbesten, L., and Clifton, J. A. (1971). Gut, 12, 257. Menguy, R., and Masters, Y. F. (1965). Surgery, Gynecology and Obstetrics,
120, 92.

Morris, C. D. W., (1967). Lancet, 1, 279.

Murray, H. S., Strottman, M. P., and Cooke, A. R. (1974). British Medical fournal, 1,19

Nahrwold, D. L. (1972). Surgery, 71, 157.

Quick, A. J. (1966). American fournal of Medical Science, 252, 265.

Rhodes, J., et al. (1969). Gastroenterology, 57, 241.

Rhodes, J. (1972). Gastroenterology, 63, 171.

Russell, R. I., et al. (1968). Lancet, 2, 603.

Russell, R. I., and Goldberg, A. (1968). Lancet, 2, 606.

Russell, R. I., et al. (1973 a). Clinical Science and Molecular Medicine, 45, 301. Russell, R. I., Gerskowitch, V. P., and Cochran, K. M. (1973 b). Personal observation.

Safaie Shirazi, S., Denbesten, L., and Hamza, K. N. (1972). Proceedings of the Society for Experimental Medicine and Biology, 140, 924.

Semple, P. F., and Russell, R. I. (1975). Gastroenterology. In press.

Werther, J. L., et al. (1970). Gastroenterology, 59, 691.

Wingate, D. J., Phillips, S. F., and Hofmann, A. F. (1973). fournal of Clinical Investigation, 52, 1230 .

\title{
Oestrogen Receptors in Breast Cancer: A Changing Concept
}

\author{
G. LECLERCQ, J. C. HEUSON, M. C. DEBOEL, W. H. MATTHEIEM
}

\section{Introduction}

Some mammary tumours contain oestrogen receptors (Wittliff 1974). Jensen et al. (1971) found a striking correlation between the presence of receptors in advanced breast cancers and the response to adrenalectomy. They are extending their studies to other therapeutic procedures and the potential clinical applications are being investigated in several centres (Braunsberg et al., 1973; Engelsman et al., 1973; Jensen et al., 1973; Leung et al., 1973 a; Trams and Maass, 1973; Savlov et al., 1974; Heuson et al., 1975). Sensitive tests for the presence of oestrogen receptors have been developed. Of these the measurement of the oestradiol-binding capacity of cytosol preparations has been found to be the most convenient. Nevertheless, concentrations of receptor measured by this method in both primary and metastatic cancers have varied greatly and it is not known whether these are true variations or whether they reflect an inherent fault in the technique. The present paper reports an investigation of this question.

\section{Materials and Methods}

Tissues.-A total of 214 primary tumours and 168 metastatic deposits were studied. They were carcinomas of various histological types in about the same proportions as in a previous study (Ledlercq et al., 1973). Forty-five invaded axillary lymph nodes were analysed in 23 mastectomy specimens together with the primary cancer. The metastatic tumours were from skin (124), lymph nodes (32), liver (5), bone (5), muscle (1), and ovary (1). The specimens were obtained at operation and within minutes or,

G. LECLERCQ, D.sc., Assistant in Chemistry

J. C. HEUSON, M.D., Chief Lecturer

M. C. DEBOEL, Technical Assistant

W. H. MATTHEIEM, M.D., Deputy Chief Surgeon 
rarely, within one to two hours were washed in cold Krebs-Ringer Henselheit glucose buffer $\mathrm{pH} 7 \cdot 3$. They were then dipped into a homogenizing buffer (trometamol (TRIS) $\mathrm{HCl} 0.01 \mathrm{~mol} / \mathrm{l}, \mathrm{pH}$ 7.5 , containing $1.5 \mathrm{mmol}$ EDTA and $6 \mathrm{mmol} \beta$-mercaptoethanol per litre) immediately before being frozen in liquid nitrogen. In all samples the presence of tumour tissue was verified histologically. Specimens of non-neoplastic mammary tissue and oestrogen nontarget tissue were obtained and treated in the same way.

Oestrogen Receptor Assay.-Oestrogen receptors in the tissue samples were assayed by measuring the binding affinity of their cytosol fraction for ${ }^{3} \mathrm{H}$-oestradiol- $17 \beta$ at $18^{\circ} \mathrm{C}$ using a method already described (Leclercq et al., 1973). The binding indices of the reaction were determined on Scatchard (1949) plots. In these co-ordinates a sloping straight line pattern indicates the presence of receptor in the tissue sample. The dissociation constant of the binding reaction is measured by the magnitude of the reverse of the slope of the line. The binding capacity, taken as the point of intersection with the abscissa, is expressed in pmol/g of either total or tissue protein, the latter being calculated by the equation (E.O.R.T.C., 1973).

$$
\text { Tissue protein }=\text { total protein }- \text { serum albumin } \times \frac{100}{60}
$$

The total protein concentration in the assay mixtures ranged from 0.5 to $8.2 \mathrm{~g} / 1$. In some experiments the assay was carried out at $2^{\circ} \mathrm{C}$ with incubation periods of 16 hours. The unbound steroid was then removed by dextran charooal at $2^{\circ} \mathrm{C}$ for 90 minutes.

Protein and Radioactivity Assay.-Total protein concentration was measured by the method of Lowry et al. (1951) using bovine serum albumin as a standard. Human serum albumin was assayed by radioimmunodiffusion on M-Partigen plates (Mancini et al., 1965). Haemoglobin was measured by the method of Crosby and Furth (1956). Radioactivity was determined by scintillation counting using Bray's (1960) solution.

\section{Results}

\section{OESTROGEN RECEPTORS IN PRIMARY AND METASTATIC TUMOURS}

Cytoplasmic oestrogen receptors were found in $156(73 \%)$ of the primary and $98(58 \%)$ of the metastatic breast cancers (table I). The findings in invaded axillary lymph nodes together with the primary tumour are analysed below. As previously reported (Leclercq et al., 1973) variations in the dissociation constant $(\mathrm{Kd})$ of the binding reaction of from 0.5 to $132 \times 10^{-10}$ mol/1 were evenly distributed among the "receptor-positive"

TABLE I-Prevalence of Oestrogen Receptors in Primary and Metastatic Tumours

\begin{tabular}{|c|c|c|c|c|c|}
\hline & \multirow[t]{3}{*}{$\begin{array}{l}\text { No. } \\
\text { studied }\end{array}$} & \multicolumn{4}{|c|}{$\begin{array}{l}\text { No. Positive for Receptors } \\
\text { According to Dissociation Constant } \\
\text { of Binding Reaction } \\
\left(\mathrm{Kd} \times 10^{-10} \mathrm{~mol} / \mathrm{l}\right)\end{array}$} \\
\hline & & \multirow{2}{*}{$0.5-20$} & \multirow{2}{*}{$>20$} & \multicolumn{2}{|c|}{ Total } \\
\hline & & & & No. & $\%$ \\
\hline $\begin{array}{l}\text { Primary tumours } \\
\text { Metastatic tumours }\end{array}$ & $\begin{array}{l}214 \\
168\end{array}$ & $\begin{array}{r}133 \\
86\end{array}$ & $\begin{array}{l}23 \\
12\end{array}$ & $\begin{array}{r}156 \\
98\end{array}$ & $\begin{array}{l}73 \\
58\end{array}$ \\
\hline
\end{tabular}

tumours without any indication of the existence of two populations of low and high values. Some $86 \%$ of these values were lower than $20 \times 10^{-10} \mathrm{~mol} / \mathrm{l}$, thus being within the range reported for the uterine receptor (Sanborn et al., 1971). The remaining $14 \%$ of values raises the question of the specificity of the corresponding binding components. The $\mathrm{Kd}$ values of the receptors were compared in several samples of a given tumour in which such a "relatively" high value was detected (tables II and III). Remarkably, except in one case (table II, case 5), an abnormally high $\mathrm{Kd}$ value was always associated with low values in most other samples from the same tumour. Furthermore, receptor-negative tumours were in most cases homogenously negative (see below).

To investigate further the specificity of our assay method samples from 21 uninvaded lymph nodes, three melanomas, one
TABLE II-Dissociation Constants of Oestradiol Receptor Complex in up to three Samples from Given Tumour in which Abnormally High Values Were Detected. Results Expressed as $K d \times 10^{-10} \mathrm{~mol} / \mathrm{l}$

\begin{tabular}{c|c|c|c}
\hline & \multicolumn{2}{|c}{ Sample } \\
\cline { 2 - 3 } Case & A & B & C \\
\hline No. & 8.5 & 41.5 & 28.9 \\
$1^{*}$ & 10.8 & 22.6 & 21.4 \\
3 & 13.9 & 22.0 & 87.3 \\
4 & 15.6 & 32.3 & \\
\hline
\end{tabular}

*Except in this case, in which the tumour was a metastasis, all were primary tumours

TABLE III-Dissociation Constants of Oestradiol Receptor Complex in Primary Tumours and Corresponding Metastatic Axillary Lymph Nodes in which Abnormally High Values Were Detected. Results Expressed as Kd $\times 10^{-10}$ mol/l

\begin{tabular}{|c|c|c|c|c|}
\hline \multirow{2}{*}{$\begin{array}{l}\text { Case } \\
\text { No. }\end{array}$} & \multirow{2}{*}{$\begin{array}{c}\text { Kd in } \\
\text { Primary Tumour }\end{array}$} & \multicolumn{3}{|c|}{ Kd in Invaded Lymph Nodes } \\
\hline & & Lower* & Middle* & Upper* \\
\hline $\begin{array}{r}6 \\
7 \\
8 \\
9 \\
10\end{array}$ & $\begin{array}{r}1.8 \\
4.9 \\
52.0 \\
53.0 \\
60.5\end{array}$ & $\begin{array}{r}2.5 \\
2.4 \\
0.7 \\
6.6 \\
14.0\end{array}$ & $\begin{array}{r}3.9 \\
\\
4.5 \\
11.1\end{array}$ & $\begin{array}{r}30.9 \\
46.5 \\
2.3\end{array}$ \\
\hline
\end{tabular}

*Level of lymph nodes.

lymphosarcoma, and one thyroid cancer were analysed. None of them showed receptor activity except for two large hypertrophied lymph nodes from mastectomy specimens. Though these were reported to be normal on pathological examination the hypertrophy suggested malignancy. The $\mathrm{Kd}$ value of the binding components of these two nodes was similar to that reported for the uterus $\left(8.5\right.$ and $\left.18.0 \times 10^{-10} \mathrm{~mol} / \mathrm{l}\right)$; their concentration was low (12 and $27 \mathrm{pmol} / \mathrm{g}$ of tissue protein). Binding activity was not detected in diluted sera from seven premenopausal and 12 postmenopausal women (the protein concentration in these samples ranged from 2.5 to $4.0 \mathrm{~g} / \mathrm{l}$ ).

\section{CHANGE IN PROPORTION OF RECEPTOR-POSITIVE TUMOURS}

During the study the proportion of tumours found to be receptor-positive progressively increased. The findings in chronological order were divided into equal parts (table IV). The proportion of positive tumours shifted from $64 \%$ to $82 \%$ and from $46 \%$ to $70 \%$ in the primary and metastatic tumours respectively. These differences were highly significant.

OESTROGEN RECEPTOR CONCENTRATION IN PRIMARY AND METASTATIC TUMOURS

In primary and metastatic tumours the concentration of receptors was variable, ranging from zero to over $1000 \mathrm{pmol} / \mathrm{g}$ of protein in an apparently even distribution. The proteins of the cytosol fractions were often contaminated to the extent of $15 \%$ to $50 \%$ by serum protein. The results were therefore corrected to obtain a more accurate assessment in terms of tissue protein. The haemoglobin content of the cytosols, measured in 16 samples, was $3 \%$ of the total protein (range $0-8 \%$ ). This contamination was considered too small to be taken into account. After correction for serum proteins the receptor

TABLE IV-Change with time in Proportion of Receptor-positive Tumours

\begin{tabular}{lc|c|c|c}
\hline & & $\begin{array}{c}\text { Specimen } \\
\text { Nos. }\end{array}$ & $\begin{array}{c}\text { Proportion } \\
\text { Positive } \\
\text { for Receptors }\end{array}$ & P \\
\hline Primary tumours & \{ & $1-107$ & $68 / 107(64 \%)$ \\
$108-214$ & $88 / 107(82 \%)$ \\
$1-84$ & $39 / 84(46 \%)$ \\
$85-168$ & $59 / 84(70 \%)$ & $\{<0.005$ \\
& \{ & &
\end{tabular}


concentrations ranged from zero to $2080 \mathrm{pmol} / \mathrm{g}$ of tissue protein, the incidence of concentration in the lower ranges being progressively greater towards the bottom (see fig). There was no indication of two populations characterized by the presence or absence of binding capacity.

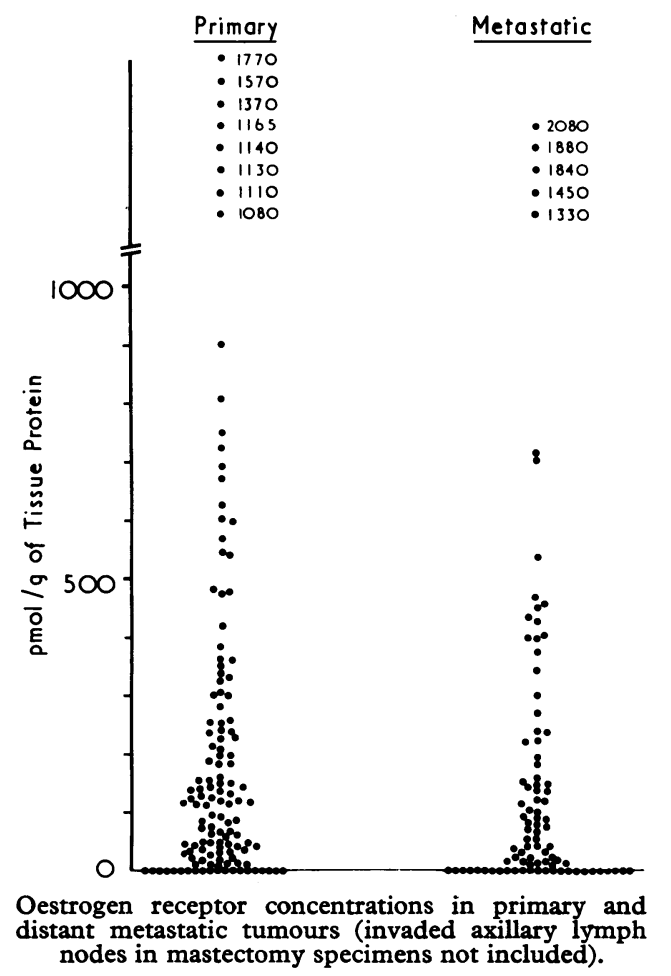

OESTROGEN RECEPTOR CONCENTRATION IN VARIOUS SAMPLES OF SAME TUMOUR

The receptor content in several samples of a tumour was measured. Except in one case, all samples from a given tumour were either positive or negative for receptors (table V). The only exception (case 18) consisted of two positive and one negative sample. The amount of receptors in the positive tumours varied between samples. Statistically, however, there was a significant correlation between the amounts in paired samples from the same tumour and these amounts could be regarded as equal $(r=0.69 ; \mathrm{P}<0.01$; see table VII, upper section).

TABLE v-Oestrogen Receptor Concentration in up to Three Samples From Same Tumour Expressed in pmol/g of Tissue Protein

\begin{tabular}{|c|c|c|c|}
\hline \multirow{2}{*}{$\begin{array}{l}\text { Case } \\
\text { No. }\end{array}$} & \multicolumn{3}{|c|}{ sample* } \\
\hline & A & B & C \\
\hline $\begin{array}{c}11 \\
12 \dagger \\
13 \\
5 \\
14 \\
15 \\
16 \\
17 \\
18 \\
1+ \\
4 \\
3 \\
2 \\
\text { (5 cases }\end{array}$ & $\begin{array}{r}525 \\
438 \\
257 \\
234 \\
156 \\
129 \\
107 \\
100 \\
34 \\
22 \\
17 \\
8 \\
4 \\
0\end{array}$ & $\begin{array}{r}344 \\
205 \\
168 \\
159 \\
226 \\
229 \\
113 \\
39 \\
102 \\
85 \\
59 \\
3 \\
72 \\
0\end{array}$ & $\begin{array}{c}0 \\
138 \\
18 \\
0 \ddagger)\end{array}$ \\
\hline
\end{tabular}

* Samples from each patient are classified in columns A to C in order of increasing Kd values of binding reactions.

†Only three samples were assayed in column $C$. From one tumour a fourth sample was tested and like the three others it contained no binding components. tExcept in cases 1 and 12, in which the tumour was a metastasis, all were primary
Twenty-three mastectomy specimens were similarly studied. Oestrogen receptors were assayed in the primary tumours and in their metastatic axillary lymph nodes. The nodes were separated into three categories according to level-namely, lower, middle, and upper. With only one exception (case 19) primary tumours and invaded nodes reacted similarly (table VI). Furthermore, in the positive specimens (omitting case 19; see footnote $(\dagger)$ to table VII) a statistically significant correlation was found between the receptor concentrations in the primary tumour and in its metastatic nodes at the various levels as well as between the concentrations in the nodes themselves, though the tumour sites varied greatly. Also, as with the paired samples from a given tumour, the concentration in the primary tumour and in its corresponding nodes were statistically equivalent (table VII). Thus from their receptor content a primary tumour and its axillary nodal metastases could be regarded as one.

TABLE VI-Oestrogen Receptor Concentrations in Primary Tumours and Invaded Axillary Lymph Nodes Expressed in pmol/g of Tissue Protein

\begin{tabular}{|c|c|c|c|c|}
\hline \multirow{2}{*}{$\begin{array}{l}\text { Case } \\
\text { No. }\end{array}$} & \multirow{2}{*}{ Primary Tumours } & \multicolumn{3}{|c|}{ Invaded Lymph Nodes } \\
\hline & & Lower & Middle & Upper \\
\hline $\begin{array}{l}19 \\
20 \\
21 \\
22 \\
9 \\
23 \\
24 \\
25 \\
7 \\
26 \\
27 \\
6 \\
10 \\
28 \\
29 \\
80 \\
3 \\
31 \\
32 \\
33 \\
34 \\
35 \\
36\end{array}$ & $\begin{array}{r}565 \\
540 \\
480 \\
354 \\
300 \\
250 \\
235 \\
183 \\
177 \\
156 \\
118 \\
108 \\
88 \\
70 \\
69 \\
59 \\
49 \\
46 \\
11 \\
8 \\
0 \\
0 \\
0\end{array}$ & $\begin{array}{r}6 \\
1820 \\
465 \\
945 \\
1080 \\
373 \\
171 \\
519 \\
167 \\
377 \\
518 \\
677 \\
17 \\
54 \\
34 \\
40 \\
66 \\
15 \\
175 \\
23 \\
0 \\
0 \\
0\end{array}$ & $\begin{array}{r}0 \\
940 \\
\\
518 \\
172 \\
\\
224 \\
314 \\
8 \\
\\
208 \\
\\
\\
14 \\
0 \\
0\end{array}$ & $\begin{array}{r}1170 \\
520 \\
\\
32 \\
205 \\
85 \\
\\
198 \\
\\
21 \\
0 \\
0\end{array}$ \\
\hline
\end{tabular}

TABLE VII-Correlation of Receptor Concentration in Two Samples of Same Tumour and in Primary Tumour and Corresponding Invaded Nodes. Results Expressed as Log pmollg of Tissue Protein

\begin{tabular}{|c|c|c|c|}
\hline \multicolumn{3}{|c|}{$\begin{array}{l}\text { Variances on Diagonal are Italicized. } \\
\text { Correlation Coefficients ( } r \text { ) are in Roman Figur es. }\end{array}$} & \multirow{2}{*}{$\begin{array}{l}\text { Mean } \\
2 \cdot 120 \\
2 \cdot 260\end{array}$} \\
\hline $\begin{array}{c}\text { Two samples from same tumour mass* } \\
\text { B }\end{array}$ & $\begin{array}{l}0.69 \\
0.359\end{array}$ & & \\
\hline $\begin{array}{l}\text { Primary tumour and corresponding axil } \\
\text { Primary tumours } \\
\text { Lower nodes } \\
\text { Middle nodes } \\
\text { Upper nodes }\end{array}$ & $\begin{array}{cc}\text { lary lymph } & \text { nodes } \\
0.69 & 0.73 \\
0.669 & 0.89 \\
& 0.703\end{array}$ & $\begin{array}{l}0.75 \\
0.72 \\
0.91 \\
0.515\end{array}$ & $\begin{array}{l}2 \cdot 373 \\
2 \cdot 477 \\
2 \cdot 452 \\
2 \cdot 455\end{array}$ \\
\hline
\end{tabular}

*Calculations were made from positive values in columns $\mathrm{A}$ and $\mathrm{B}$ of table V. Correlation coefficient is significant at level of $P<0.01$.

†Calculations were made from positive values given in table VI. Values in case 19 were omitted from study because they had the properties of outliers; logarithm of ratio of values (primary tumour over lower and axillary node) was 4.6 standard deviations removed from mean ratio of other patients. Significance levels for correlation coefficients are: $\mathrm{r}=0.69, \mathrm{P}<0.001 ; \mathrm{r}=0.73, \mathrm{P}<0.05 ; \mathrm{r}$
$\mathrm{P}=0.05 ; \mathrm{r}=0.89, \mathrm{P}<0.01 ; \mathrm{r}=0.72, \mathrm{P}<0.1 ; \mathrm{r}=0.91, \mathrm{P}<0.01$.

Statistical Summary.-A $t$ test for equality of means and variances disclosed no significant difference between any of them. This indicates, in the presence of a represents the appropriate interpretation of the data.

OESTROGEN RECEPTOR CONCENTRATION IN NON-NEOPLASTIC MAMMARY TISSUE

Primary tumours are often contaminated by varying amounts of non-neoplastic mammary tissue. Oestrogen receptor determinations were therefore carried out in various non-malignant tissues of the breast to evaluate their possible contribution to the assay. Receptors were never found in normal mammary glands of women, nipple, areola, or skin (table VIII) but there were detectable amounts in some samples from benign mammary 
dysplasia, fibroadenoma, papilloma, and male gynaecomastia. The receptor content in these tissue samples ranged up to $182 \mathrm{pmol} / \mathrm{g}$ of tissue protein, which was lower on average than in the malignant tumours.

Hence benign mammary dysplastic tissue in samples of cancer could contribute to the receptor activity. Nevertheless, in one series of breast cancer specimens mixed with large amounts of dysplastic lesions the proportion of receptornegative samples was $30 \%$ (6 out of 20 ), which was close to that in the whole series.

rABLE VIII-Assay of Oestrogen Receptor in Various Non-malignant Mammary Tissues

\begin{tabular}{l|c|c|c}
\multicolumn{1}{c|}{ Tissue sample } & $\begin{array}{c}\text { No. of } \\
\text { Samples } \\
\text { Studied }\end{array}$ & $\begin{array}{c}\text { No. Positive } \\
\text { for } \\
\text { Receptors }\end{array}$ & $\begin{array}{c}\text { Receptor Concentration } \\
\text { (pmol/g } \\
\text { of Tissue Protein) }\end{array}$ \\
\cline { 1 - 1 } \begin{tabular}{l|c|c} 
Benign mammary \\
dysplasia
\end{tabular} & 10 & 4 & $34-157$ \\
$\begin{array}{l}\text { Fibroadenoma } \\
\text { Papilloma }\end{array}$ & 8 & 4 & $29-182$ \\
$\begin{array}{l}\text { Normal mammary gland } \\
\text { (woman) }\end{array}$ & 5 & 1 & 19 \\
$\begin{array}{l}\text { Normal mammary gland } \\
\text { (male gynaecomastia) }\end{array}$ & 5 & 0 & \\
$\begin{array}{l}\text { Nipple } \\
\text { Areola }\end{array}$ & 4 & 3 & $15-138$ \\
Skin & 3 & 0 & \\
\hline
\end{tabular}

\section{INFLUENCE OF TEMPERATURE ON BINDING REACTION}

To rule out artefacts due to temperature in our method (McGuire and DeLaGarza, 1973) six cytosol fractions were incubated with ${ }^{3} \mathrm{H}$-oestradiol- $17 \beta$ at $2^{\circ}$ and $18^{\circ} \mathrm{C}$. Under both conditions the cytosols contained high-affinity binding sites. The $\mathrm{Kd}$ values and number of binding sites (table IX) showed that the incubation temperature did not affect the results.

TABLE IX-Binding Indices of Oestrogen Receptors at $2^{\circ}$ and $18^{\circ} \mathrm{C}$

\begin{tabular}{|c|c|c|c|c|}
\hline \multirow[b]{2}{*}{ Case No. } & \multicolumn{2}{|c|}{$2^{\circ} \mathrm{C}$} & \multicolumn{2}{|c|}{$18^{\circ} \mathrm{C}$} \\
\hline & $\begin{array}{c}\text { Kd Value } \\
\left(\mathrm{x} 10^{-10}\right. \\
\mathrm{mol} / \mathrm{l})\end{array}$ & $\begin{array}{c}\text { Receptor } \\
\text { Concentration } \\
\text { (pmol/g of } \\
\text { Tissue Protein) }\end{array}$ & $\begin{array}{c}\text { Kd Value } \\
\left(\times 10^{-10}\right. \\
\mathrm{mol} / \mathrm{l})\end{array}$ & $\begin{array}{c}\text { Receptor } \\
\text { Concentration } \\
\text { (pmol/g of } \\
\text { Tissue Protein) }\end{array}$ \\
\hline $\begin{array}{l}37 \\
38 \\
39 \\
40 \\
41 \\
42\end{array}$ & $\begin{array}{l}0.6 \\
0.3 \\
5.4 \\
0.5 \\
3.0 \\
3.7\end{array}$ & $\begin{array}{r}620 \\
306 \\
250 \\
212 \\
186 \\
54\end{array}$ & $\begin{array}{l}1 \cdot 3 \\
1 \cdot 2 \\
4 \cdot 0 \\
2 \cdot 5 \\
2 \cdot 4 \\
6 \cdot 3\end{array}$ & $\begin{array}{r}551 \\
297 \\
233 \\
230 \\
167 \\
54\end{array}$ \\
\hline
\end{tabular}

\section{Discussion}

In a paper describing the early part of this work (Leclercq et al., 1973) we reported oestrogen receptors in primary and metastatic breast cancers in $56 \%$ (43 out of 77) and $37 \%$ (24 out of 65 ) of cases respectively. The present findings suggest that these proportions were underestimated and that many more breast cancers contain detectable amounts of oestrogen receptors. In the second half of the study, without any modification of the biochemical procedure, the respective rates of receptor-positive tumours were $82 \%$ (primary tumours) and $70 \%$ (metastases) as against $64 \%$ and $46 \%$ in the first half. Co-ordination with the clinical departments taking part in the study improved steadily, and better handling of the tissue from the operating room to the laboratory may have helped to increase the incidence of receptor-positive tumours. Most probably the later results were more accurate than the earlier ones.

Our finding of a higher proportion of receptor-positive cases than in all other series (Wittliff, 1974) could be because we supplemented the homogenizing buffer with $\beta$-mercaptoethanol. The other investigators did not do this. The protective effect of thiol reagents was recently shown (Braunsberg et al., 1972;
McGuire and DeLaGarza, 1973). We found that in their presence the receptors were as stable at $18^{\circ} \mathrm{C}$ for 30 minutes as at $2^{\circ} \mathrm{C}$ for 16 hours. Our use of the higher incubation temperature was therefore entirely compatible with the method recommended at an E.O.R.T.C. (1973) workshop.

The $\mathrm{Kd}$ values of the binding reactions varied among tumours within a wider range than in the uterine tissue. This raised the question of specificity of the binding components with relatively high $\mathrm{Kd}$ values. Comparison of the $\mathrm{Kd}$ values between samples of a given tumour and between the primary tumour and its metastatic axillary lymph nodes showed that the related samples were almost always either negative or positive in terms of containing binding components, and that when they were positive high and low $\mathrm{Kd}$ values could be present together. Also nonmammary tissues and sera were not found by the present method to contain detectable binding activity with low or high $\mathrm{Kd}$ values. These arguments strongly favour the view that the binding components with high $\mathrm{Kd}$ values are specific oestrogen receptors. These values probably reflect either alteration of the receptor or inaccuracy of their characterization by the assay method (Leclercq et al., 1973).

The concentration of receptor was found to be highly variable among both primary and metastatic tumours. The question is whether a similar variability exists within a given tumour or whether a tumour is characterized by a particular level of receptivity. Investigation of various samples of the same tumour showed, with only one exception in 19 experiments, that all samples displayed the same reactivity. Furthermore, statistical analysis established that all samples of positive tumours contained similar levels of receptor, even if the reproducibility of the determination was only moderate owing mainly to the heterogeneity of the tissue. Thus a given tumour may be defined by its levels of oestrogen receptivity and breast cancers differ from one another in this respect.

As reported (Leclercq et al., 1973; Spaeren et al., 1973) invaded axillary lymph nodes and their corresponding primary tumours were similar with regard to the presence or absence of receptor. The present study suggested that the concentration of receptor in primary tumours and their axillary nodal metastases is the same within the limits of sampling variations for a given tumour. This similarity holds even between primary tumours and their most distant metastases (nodes at the upper level). This suggests that the primary tumours are composed of a single population of cells in respect of oestrogen receptivity and that this property is not modified in the processes of cell division and migration. Nevertheless, if distinct populations of cells exist in a given tumour it would seem that they have exactly the same propensity to metastasize to axillary lymph nodes and that no cell selection occurs during the aforementioned processes. One case in our study (case 19) differed from all the others and might have represented a rare but possible transformation or selection. Further studies are in progress to establish whether tumour stability is maintained during the whole course of the disease and especially at the time of dissemination of distant metastases.

The high sensitivity of the method used in our study may explain why the results differ from most others reported, in which benign mammary tissues rarely contained detectable amounts of oestrogen receptors (Johansson et al., 1970; Feherty et al., 1971; Hähnel et al., 1971; Korsten and Persijn, 1972; Wittliff et al., 1972; Leung et al., 1973 b). Notably, however, only hyperplastic tissues (benign dysplasia, fibroadenoma, papilloma) contained receptors, whereas the normal female mammary gland apparently did not. Nipple, areola, and breast skin also failed to show binding activity. Remarkably, male gynaecomastia, which may also be regarded as hyperplastic breast tissue, contained receptors in some cases. A possible causal relationship between the presence of receptors and hyperplasia as well as neoplasia should be considered.

Our study shows that most breast cancers contain oestrogen receptors. The even distribution of receptor concentrations and apparent absence of two distinct tumour populations suggest 
that some or even possibly all "negative" breast cancers may contain receptors in undetectable amounts. This leads to the concept that breast cancers should no longer be regarded as hormone dependent or independent but rather as having varying degrees of dependence. It is particularly interesting that we found that a given tumour may be characterized by its receptor content. Quantitative measurement of this content might assess the degree of hormone dependence of a tumour. We therefore suggest that quantitative rather than qualitative assessment should provide an appropriate criterion in future studies of biochemical and clinical correlations.

We thank the Service d'Anatomie Pathologique, Institut Jules Bordet, for examining the tumours. We also acknowledge the kind help of Dr. J. S. Williams (E.O.R.T.C. Data Center, Institut Jules Bordet) with the statistical analysis of the results, and Professor H. T. Tagnon for discussing the concepts presented.

The sources of the reagents used in the study were as follows: $(2,4,6,7)-{ }^{3} \mathrm{H}$-oestradiol- $17 \beta 100 \mathrm{Ci} / \mathrm{mmol}$ was purchased from the Radiochemical Centre, Amersham, England; charcoal from Merck, Darmstadt, Germany; dextran T-70 from Pharmacia, Uppsala, Sweden; bovine serum albumin fraction $\mathrm{V}$ from the Sigma Chemical Company, St. Louis, Mo., U.S.A.; and M-Partigen plates from Behring-Marburg-Lahn, Germany. All the reagents were analytical grades.

This work was supported by a grant from the Fonds Cancérologique de la Caisse Générale d'Epargne et de Retraite de Belgique and performed within the framework of the Association Euratom, University of Brussels, and University of Pisa.

\section{References}

Braunsberg, H., Killen, E., and Richardson, S. G. (1972). Biochemical fournal, 130, 38p.

Braunsberg, H., et al. (1973). Lancet, 1, 163.

Braunsberg, H., et al. (1973). Lancet, 1, 163.

Bray, G. A. (1960). Analytical Biochemistry, 1, 179.

Erosby, W. H., and Furth, F. W. (1956). Blood, 11, 380.

Engelsman, E., et al. (1973). British Medical fournal, 2,

Feherty, P., Farrer-Brown, G., and Kellie, A. E. (1971). British fournal of Cancer, 25, 697.

Hähnel, R., Twaddle, E., and Vivian, A. B. (1971). Steroids, 18, 681.

Heuson, J. C., et al. (1975). Fournal de Gynécologie Obstétrique de la Reproduction. In pres.

Jensen, E. V., et al. (1971). National Cancer Institute Monographs, 34, 55.

Jensen, E. V., et al. (1973). Recent Results in Cancer Research, No. 42, p. 55. London, Heinemann.

Johansson, H., Terenius, L., and Thorén, L. (1970). Cancer Research, 30, 692.

Korsten, C. B., and Persijn, J.-P. (1972). Zeitschrift für klinische Chemie und klinische Biochemie, 10, 502.

Leclercq, G., et al. (1973). European fournal of Cancer, 9, 665.

Leclercq, G., et al. (1973). European fournal of Cancer, $9,665$.

Leung, B. S., et al. (1973 a). Archives of Surgery, 106, ung, B. S.; Manaugh, L. C., and Wood, D. C. (1973 b). Clinica Chimica Acta, 46, 69.

Lowry, O. H.; et al. (1951). Fournal of Biochemical Chemistry, 193, 265.

McGuire, W. L., and DeLaGarza, M. (1973). Fournal of Clinical Endocrinology and Metabolism, 37, 986.

Mancini, G., Carbonara, O. A., and Heremans, J. F. (1965). Immunochemistry, 2, 235.

Sanborn, B. M., Rao, B. R., and Korenman, S. G. (1971). Biochemistry, 10, 4955 .

Savlov, E. D., et al. (1974). Cancer (Philadelphia), 33, 303.

Scatchard, G. (1949). Annals of the New York Academy of Sciences, 51, 660.

Spaeren, U., et al. (1973). European fournal of Cancer, 9, 353.

Trams, G., and Maass, H. (1973). Archiv fitr Gynäkologie, 214, 293.

Trams, G., and Maass, H. (1973). Archiv für Gynä

Wittliff, J. L., et al. (1972). Cancer Research, 32, 1983.

\section{The HL-A System in Asbestos Workers}

\section{J. A. MERCHANT, P. T. KLOUDA, C. A. SOUTAR, W. RAYMOND PARKES, SYLVIA D. LAWLER, MARGARET TURNER-WARWICK}

British Medical Fournal, 1975, 1, 189-191

\section{Summary}

In a study of the HL-A system in 56 selected asbestos workers referred to the Pneumoconiosis Medical Panel with definite or suspected asbestosis, the $W 27$ antigen was found more often than among a control population. Six of the 10 asbestos workers with the $W 27$ antigen had definite radiographic evidence of asbestosis compared to 13 out of 46 without the $W 27$ antigen. These observations, if confirmed, suggest that the $W 27$ antigen may provide a useful marker of an enhanced susceptibility to the tissue-damaging effects of asbestos dust.

\section{Introduction}

The incidence and severity of asbestosis-that is, pulmonary fibrosis-are to some extent related to the concentration of dust

Department of Medicine, Cardiothoracic Institute, London SW3 6HP J. A. MERCHANT, M.D., DR.P.H., Brompton Fellow

C. A. SOUTAR, M.B., M.R.C.P., Lecturer

W. RAYMOND PARKES, M.D., M.R.C.P., Honorary Lecturer (Member of Pnemaconiosis Medical Panel)

MARGARET TURNER-WARWICK, D.M., F.R.C.P., Professor of Thoracic Medicine

Department of Cytogenics and Immunology, Royal Marsden Hospital and Institute of Cancer Research, London S.W.3

P. T. KLOUDA, PROM.BIOL., Lecturer

SYLVIA D. LAWLER, M.R.C.P., F.R.C.PATH., Consultant Immunologist and the time since first exposure. This relationship, however, is weaker than in coal pneumoconiosis (Rossiter, 1972). Appreciable differences in the severity of lung disease occur in individuals with apparently similar exposure to asbestos dust, which raises the possibility that unrecognized host factors may alter the individual response to asbestos dust inhalation. That one or more of these host factors may depend on immunological responses in the lung has been suggested by the finding of an increased frequency of antinuclear antibody (A.N.A.) and rheumatoid factor in patients with asbestosis (Pernis et al., 1965; Turner-Warwick and Parkes, 1970) and coal pneumoconiosis (Lippman etal., 1973; Soutar et al., 1974).

Some immune-response genes are believed to be closely linked to the HL-A system-the major histocompatibility system in man-and HL-A antigens have been found to be associated with some diseases having immunological abnormalities (Caffrey and James, 1973; Brewerton et al., $1973 \mathrm{a}, \mathrm{b}, \mathrm{c}$; Schlosstein et al., 1973).

A pilot study of the HL-A system in asbestos workers was therefore undertaken to search for evidence of inherited differences in susceptibility to asbestosis.

\section{Patients and Methods}

The 56 asbestos workers were selected from a study undertaken with the Pneumoconiosis Medical Panel, to which they had been referred because of suspected asbestosis. All had been occupationally exposed to asbestos, mainly as laggers in the insulation industry or in dockyards. Clinical data were recorded on a standard questionnaire, posteroanterior and lateral chest radiographs were taken, and venous blood samples were obtained. All subjects were Caucasian and all but one were men. Their mean age was 57 years (range 37-73), mean duration of exposure to asbestos 22 years $(1-47)$, and mean time since 